\title{
Effect of Business Management Training on Financial Performance of Deposit Taking Saccos in Kenya
}

\author{
Ezra K. Ronoh ${ }^{1 *}$, Njenga Gitahi Samson ${ }^{1}$, Prof Peter B. Kibas ${ }^{2}$, Dr. Patrick Kibati ${ }^{1}$ \\ ${ }^{1}$ School of Business and Economics, Kabarak University, Kenya \\ ${ }^{2}$ Presbyterian University of East Africa, Kenya
}

*Corresponding Author: Ezra K. Ronoh, School of Business and Economics, Kabarak University, Kenya

\begin{abstract}
This research only focused on the effect of Business Management Training on Financial Performance of DT-SACCOs with respect to the constructs of Accounting Skills, Entrepreneurship Skills, Financial Management Skills, Marketing Management Skills and Strategic Leadership Skills. The theories that underpin this study were; theory of internal control, psychological theory, financial stewardship theory, resource based theory and porter's theory of competitive advantage. This study applied both positivistic and interpretivism philosophical foundations. It adopted explanatory survey design to answer the research questions. The target population was 176 licensed DT-SACCOs in Kenya. Random sampling technique was used to obtain 74 DT-SACCOs which provided 3 respondents each. Primary data was collected using structured questionnaires with a likert scale while secondary data collection sheet was used for collecting information concerning DT-SACCO's financial performance. A drop and pick later technique was used. Reliability (cronbach alpha) and validity were used to pre-test the research questionnaire. Data was analyzed using both inferential (correlation and regression) and descriptive (frequencies, percentages, mean and standard deviation) statistics using Statistical Package for Social Sciences (SPSS). The qualitative data was coded and classified into major themes from which a summary report was made. The correlation analysis results of the study show a significant positive relationship between all the independent variables (accounting skills, entrepreneurship skills, financial management skills, marketing skills and strategic leadership skills) and financial performance. Based on the results of the multiple regressions, the five independent variables could explain only $41.4 \%$ of the changes in financial performance. After the interaction of SASRA Regulations, an $R$ Square Change of 0.613 showed that addition of its effect to the model led to $61.3 \%$ increase in variation of financial performance and as such the increase was statistically significant. The study thus concluded that all the variables under study were statistically significant in explaining the financial performance of DT-SACCOs in Kenya. The study recommends that the DT-SACCOs should; put tighter internal controls system for proper business accounts management, hire managers based on an entrepreneurial inclination and set objectives for value maximization to be attained complimented by a vision. Further, it should focus on both human and financial resources to penetrate the market and use competitive forces strategy to defend themselves against competition.
\end{abstract}

Keywords: Accounting skills, entrepreneurship skills, financial management skills, marketing management skills, Strategic Leadership skills, financial performance, Deposit Taking Savings and Credit Cooperative Societies.

\section{BACKGROUND OF THE STUDY}

Human Resources is the main asset for the organization or agency. Therefore there is a need for human resources who are knowledgeable, qualified, capable and competitive, so as to be able to develop or maintain the position of the organization/ agency in a competitive environment. Human resource factor is the prime mover of a business unit. Progress and success of a business is determined by the quality of human resources of the perpetrators of business. Managerial ability, leadership ability, financial management ability are very influential on the performance of business as a whole (Macherinskiene, Irene and Survilaite, 2011). To develop the desired knowledge,skills and abilities of employees to perform well on the job, requires effective Business management training programs that may also affect positively employee motivation and commitment (Amir and Amen, 2013). 


\subsection{Statement of the problem}

In Kenya, the DT-SACCOs mainly receive their training from KUSCCO, mandated by the Government. C.E.Os/ managers and staff undergo Business Management Training under their training calendar. Other institutions offering training in the SACCO sector includes; Kenya School of Government, Kenya School of Credit Management and Kenya Institute of Management (KIM). However, despite the government initiative to introduce these trainings, research has not revealed the exact relationship between Business Management Training and Financial performance of DTSACCOs in Kenya. This study sought to close this information gap by providing empirical evidence. Hence, this study investigated the effect of acquired Accounting Skills, Entrepreneurship Skills, Financial Management Skills, Marketing Management Skills and Strategic Leadership Skills on the Financial Performance of DT-SACCOs in Kenya.

\subsection{Research Objectives}

\subsubsection{General Objectives}

To assess the effect of Business Management Training on Financial Performance of DT-SACCOs in Kenya.

\subsubsection{Specific Objectives}

- To assess the effect of acquired accounting skills on financial performance of DT-SACCOs in Kenya.

- To establish the effect of acquired entrepreneurship skills on financial performance of DTSACCOs in Kenya.

- To determine the effect of acquired financial management skills on financial performance of DT-SACCOs in Kenya.

- To establish the effect of acquired marketing skills on financial performance of DT-SACCOs in Kenya.

- To determine the effect of acquired Strategic Leadership skills on financial performance of DT-SACCOs in Kenya.

- To find out the moderating effect of SASRA regulation on the relationship between business management training and financial performance of DT-SACCOs in Kenya.

\subsection{Hypotheses of the Study}

$\mathrm{H}_{01}$ : Acquired Accounting skills have no statistically significant effect on financial performance of DT-SACCOs in Kenya.

$\mathrm{H}_{02}$ : Acquired Entrepreneurship skills have no statistically significant effect on financial performance of DT-SACCOs in Kenya.

$\mathrm{H}_{03}$ : There is no statistically significant effect of acquired financial management skills on financial performance of DT-SACCOs in Kenya.

$\mathrm{H}_{04}$ : There is no statistically significant effect of acquired marketing skills on financial performance of DT-SACCOs in Kenya.

$\mathrm{H}_{05}$ : There is no statistically significant effect of acquired Strategic Leadership skills on financial performance of DT-SACCOs in Kenya.

Ho6: There is no statistically significant moderating effect of SASRA regulation on the relationship between business management training and financial performance of DT-SACCOs.

\section{LITERATURE REVIEW}

The theories which underpin this study include; theory of internal control, psychological theory, financial stewardship theories, resource-based theory and porters theory of competitive advantage.

\subsection{Theory of Internal Control}

The theory of internal control was presented for the first time in 1949 by the American Institute of Certified Accountants (AICPA). The proposition explains internal control as a plan and other 
coordinated means and ways by the enterprise to keep safe its assets, check the covertness and reliability of data, to increase its effectiveness and to ensure the settled management politics. A system of effective internal control is a critical component of an organizations management and a foundation for its safe and sound operation. A system of strong internal control can help to ensure that the goals and objectives of an organization will be met, that it will achieve long term targets and maintain reliable financial and managerial reporting. Such a system can also help to ensure the organization will comply with laws and regulations as well as policies, plans, internal rules and procedures and reduce risk of unexpected losses and damage to the organizations reputation. This system of strong internal controls can only be achieved through staff and management training in accounting skills (Barnabas, 2011).

\subsection{Psychological Entrepreneurship Theory}

This theory emphasizes personal characteristics that define entrepreneurship. Need for achievement, locus of control and personality traits are reviewed below and have been found to be associated with entrepreneurial inclination. Need for achievement trait of Psychological theory put forward by Psychologist David McClelland (1961) explained that human beings have a need to succeed, accomplish, excel or achieve. Entrepreneurs are driven by this need to achieve and excel and reinforced through training to make them focused in their venture. While there is no research evidence to support personality traits, there is evidence for the relationship between achievement motivation and entrepreneurship (Johnson, 1990). Achievement motivation may be the only convincing person logical factor related to new venture creation (Shaver \& Scott, 1991). The high need for achievement by DT-SACCO managers tends to make them take personal responsibility and calculated risks.

\subsection{Financial Stewardship Theory}

The Steward theory developed by Donaldson and Davis (1991 \& 1993), is a new perspective to understand the existing relationship between owners and management of a company. Donaldson \& Davis (1991) contends that this theory recognizes the importance of structures that empower the steward and offers maximum autonomy built on trust. A Steward protects and maximizes shareholders wealth through firm performance, because by so doing, the steward's utility is maximized (Davis et al. 1997). In this perspective, Stewards are managers working to protect and make profits for shareholders. Therefore, Steward theory emphasizes the role of management being Stewards, integrating their goals as part of the organization (Davis et al.,1997). The Stewardship perspective suggest that Stewards are satisfied and motivated when organizational success is attained. The theory recognizes the importance of governance structures that empower the steward and offers maximum autonomy built on trust (Donaldson \& Davis, 1991). It stresses the position of employee to act more autonomously so that the shareholders returns are maximized. Indeed this can minimize the costs aimed at monitoring and controlling employee behavior (Davis et a., 1997).

\subsection{Resource Based Theory}

Resource based theory is an approach to achieving competitive advantage that emerged in the 1980s and 1990s after major works published by Wernefelt (2010) and Barney (2009). It is one of the most influential theories in the history of management theorizing. It aspires to explain the internal sources of firm's sustained marketing effectiveness (Kraaijenbrink, Spender\&Groen, 2010). Penrose established the foundations of the resource based view as a theory (Roos\&Roos, 2012). He first provides a logical explanation to the growth rate of the firm by clarifying the causal relationships among firm resources, production capability and performance. Her concern is mainly on efficient and innovative use of resources. She claimed that bundles of productive resources controlled by firms could vary significantly by firm and that firms in this sense are fundamentally heterogeneous even if they are in the same industry (Barney \& Clark, 2014). Wernerfelt (2010) took on a resource perspective to analyze antecedents of products and ultimately organizational performance and believed that "resources and products are two sides of the same thing and firm's diversity is based on available resources and continue to accumulate through acquisition behaviors".

\subsection{Porter's Theory of Competitive Advantage}

The dominant paradigm in strategy at least during the 1980s was the competitive forces approach pioneered by Porter (1980). The competitive forces approach was the essence of competitive strategy 
formulation as relating a company to its environment. The key aspect of the firms environment is the industry or industries in which it competes. Industry structure strongly influences the competitive rules of the game as well as the strategies potentially available to firms. In the competitive forces model, five industry level forces; entry barriers, threat of substitution, bargaining power of buyers, bargaining power of suppliers and rivalry among industry or sub-segment of an industry.

\section{SUMMARY AND RESEARCH GAPS}

The literature so far reviewed indicates that factors influencing the financial performance of DTSACCOs are multifaceted and they purely depend on the operating environment of the DT-SACCO, Business Management Training being one factor. It is therefore worth noting that DT-SACCOs operate in a unique environment compared to other forms of business and hence the need to understand the forces and factors determining their performance. Satgar and Williams (2008) asserts that the cooperative movement is one of the most organized social forces on the African continent. They cite the ILO which suggests that 7 percent of citizens in African countries belong to cooperatives, rising in countries like Mauritius, Egypt, Ghana, Kenya and Senegal to 10 percent or more. The cooperative movement in Africa plays a crucial role in economic and social transformation and in many parts of Africa.

The study examined a number of research works on the factors affecting the performance of DTSACCOs; Bhuyan (2007) who cited lack of members' participation, Nyoro and Ngugi (2007) cited the economic factors, education management committee and the staff. Makori, Munene and Muturi (2013) cited high dependency of short term borrowing, lack of liquidity, monitoring, political interference, investment in non-earning assets and inadequate managerial competence. Auka and Mwangi (2013) posited lack of competitive advantage of SACCO products and services as compared to other service providers. Kilonzo (2010) cited shocks impinging on the economic system and the lack of the proper policy to mitigate the effects of these shocks. Kiaritha (2015) cited competition, internal politics, operating costs, saving culture and investment policy as determinants of financial performance of SACCOs. Business Management Training provided to the DT-SACCO management is a unique factor which needs to be investigated to determine its effect on financial performance of DT-SACCOs. No other study has been done to establish its effect on the financial performance of DTSACCOs based on a combination of the variables considered in this study. It is in the face of such that this study aims at filling the gap, by establishing the effect of business management training on financial performance of DT-SACCOs in Kenya.

Another gap which this study endeavored to fill is the contradiction showing one group of literature indicating that Business Management Training affects Financial Performance of DT-SACCOs and the other showing that it does not. According to Rowden and Conine (2005), the purpose of training is to enhance the satisfaction of employees towards their jobs and satisfied employees contend their customers with enhanced performance. Employees who commit to learn are more satisfied with their jobs and ultimately show more positive performance than others (Tsai et al, 2007). In line with Tsai (2007), Harrison (2000) established that learning that is prompted by training positively effects employee performance and is an essential element for the achievement of organizational goals (Harrison, 2000). Similarly perceived training effectiveness is highly correlated with the job satisfaction of employee, supporting the findings of Tsai et al (2007). More recent research however, reveals that few studies detect significant effects of business training on business profits or sales, although the confidence intervals are very wide in many cases. Berge et al. (2011) finds that training increases profits by $24 \%$ and sales by $29 \%$ for males in the short run (5 to 7 months post-training), but the point estimate of the impact on profits drops to 5\% and is statistically insignificant in their longerterm follow up (30 months post training), there is a continued and marginally significant impact on sales. De Mel, (2012) found no effect of training alone on profits of existing firms over either the short or medium run but they do find significant effect of the combination of training and a grant on short-run profits, with these gains dissipating over time. Calderon et al. (2012) found a $24 \%$ increase in weekly profits and a $20 \%$ increase in weekly revenues. Valdivia (2012) found a $20 \%$ increase for the group that received both training and intensive one-on-one technical assistance but no significant increase for training alone, while Glaub et al (2012) found a positive effect of personal initiative training on sales one year later. Several studies have emphasized the possibility of business training having its strongest impact on sales during a bad month noting that it might help clients identify strategies to reduce downward fluctuations in sales by considering diversifying the products they offer 
and by being more proactive about alternative activities during slow months (Karlan\& Valdivia (2011), Dexlar, (2012). However, other studies by Gine and Mansuri (2011), De Mel, (2012) and Valdivia (2012) find no significant impact of training alone on sales during bad months. Thus reviewing these studies together led us to conclude that the theory that training has particularly strong effects during bad periods is weak. It is aimed that this study will build upon and expands existing knowledge on the effect of Business Management Training on Financial Performance of DT-SACCOs in Kenya by addressing this contradictory gap.

\section{CONCEPTUAL FRAMEWORK}

Mugenda(2008) defines conceptual framework as a concise description of the phenomenon under study accompanied by a graphical or visual depiction of the major. Mugenda(2008) furthers defines conceptual framework as a concise depiction of the variables of the study. Kothari (2004) defines an independent variable also known as the explanatory variable as the presumed cause of the changes of the dependent variable, while the dependable variable refers to the variable which the researcher wishes to explain. According to young (2009), conceptual framework is a diagrammatical representation that shows the relationship between dependent variable and independent variables. In the study, the conceptual framework will examine the effect of business management training on financial performance DT-SACCOs in Kenya. The research hypothesized a causal relationship between the financial performance (FP) of SACCOs with each of the independent variable namely; Accounting Skills (AS), Entrepreneurship Skills(E/S), Financial Management Skills (FS), Marketing Skills (MS) and Strategic Leadership Skills (SM) as indicated in figure 2.1 on the next page.

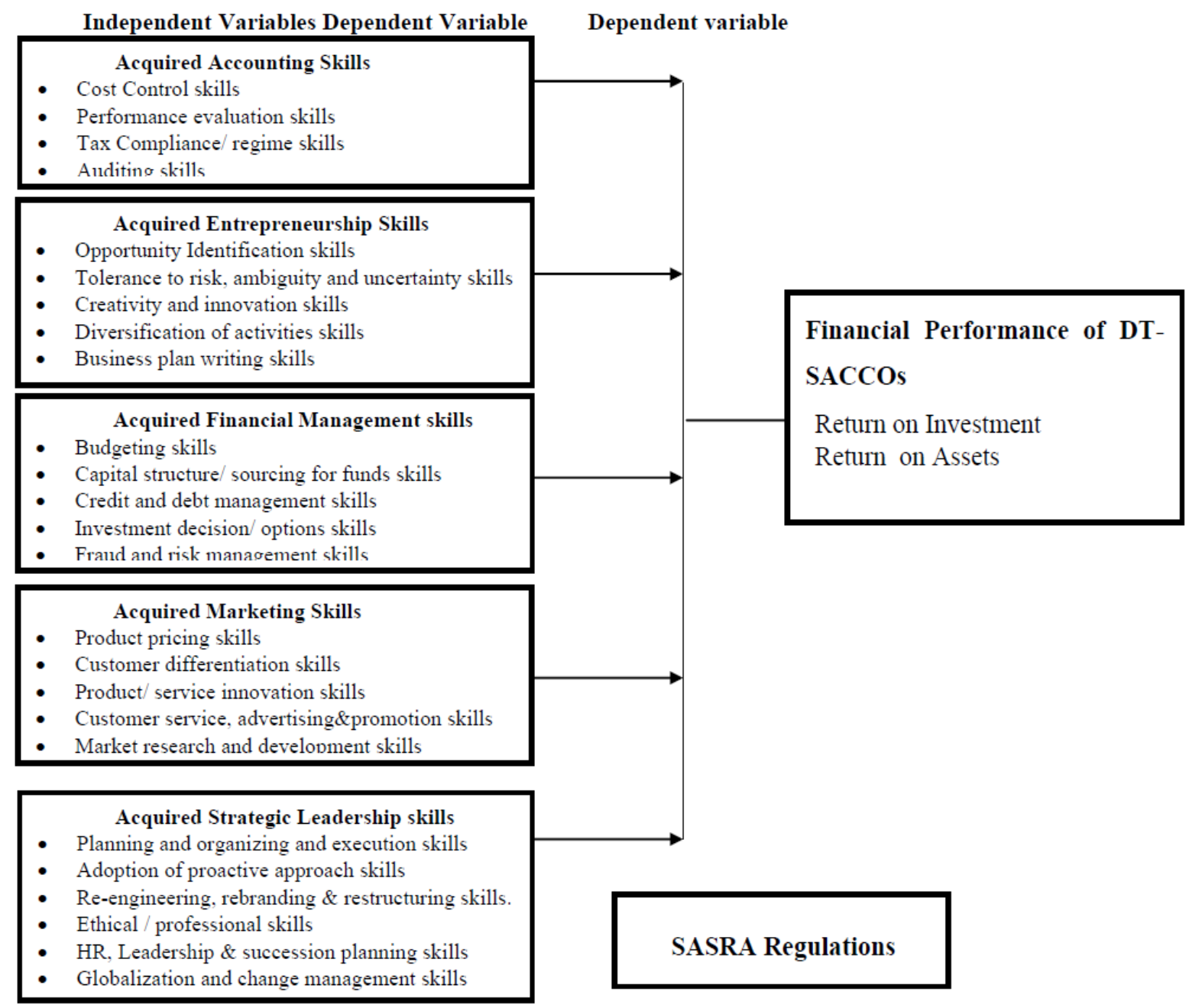

\section{RESEARCH METHODOLOGY}

\subsection{Research Philosophy}

This study applied both positivistic and an interpretivist philosophical foundation since the study was based on the effect of business management training on financial performance among DT-SACCOs. 


\subsection{Research Design}

The researcher used explanatory survey design since data to be collected will be standardized thus allowing easy comparison. Explanatory survey design is a method of collecting data by administering a questionnaire to a sample of individuals which can be used when collecting information about people's attitudes, opinions, habits or any other social issues (Orodho, 2003).

\subsection{Target Population}

In Kenya there were one hundred and seventy six (176) registered DT-SACCOs as at December, 2016. Out of the 176 DT-SACCOs, 3 senoir officials were selected as respondents giving a total population of 528. The accessible population was 74 DT-SACCOs registered by SASRA within the randomly selected SACCOs in Kenya. The researcher undertook an analysis of performance of the randomly selected DT-SACCOs and established their location in the Country.

\subsection{Sample Design and Sample Size}

The sampling frame of this study was derived from the database of SASRA. Regarding the DTSACCO as the unit of analysis, the researcher adopted random sampling technique.

\section{Data Collection}

Questionnaires were used to enable the study reach a large group of respondents within a short time and at fewer costs.

\subsection{Data Collection Procedures}

\subsubsection{Data Analysis and Presentation}

Data analysis was done using both descriptive and inferential statistics. This was achieved using descriptive statistics which is the assessment of central tendency (convergence) and dispersion (divergence).The data was presented in form of tables and charts. The study used chi-square of test association between financial performance on acquired accounting skills, entrepreneurship skills, financial management skills, marketing management skills and Strategic Leadership skills. Multiple regressions and correlations was done in order to determine the nature of the relationship between the independent and dependent variable.

The multiple regression model is as laid below.

$$
\mathbf{Y}=\boldsymbol{\beta}_{0}+\boldsymbol{\beta}_{1} \mathbf{X}_{1}+\boldsymbol{\beta}_{2} \mathbf{X}_{2}+\beta_{3} X_{3}+\beta_{4} X_{4}+\beta_{5} X_{5}+\varepsilon
$$

Where;

$\mathrm{Y}=$ Financial performance as measured by Return on Investment

$\beta_{0=}$ Constant

$\beta_{1,}, \beta_{2}, \beta_{3}, \beta_{4}, \beta_{5}$ are regression coefficients

$\mathrm{X}_{1=}$ Accounting Skills.

$\mathrm{X}_{2=}$ Entrepreneurship Skills

$\mathrm{X}_{3=}$ Financial Management Skills

$\mathrm{X}_{4=}$ Marketing Skills.

$\mathrm{X}_{5=}$ Strategic Leadership Skills

$\varepsilon=$ Error term: difference between the calculated dependent variable value and the actual value.

The regression model was tested on how well it fits the data. Fischer distribution test called F-test was applied. It refers to the ratio between the model mean square divided by the error mean square at 5 percent significant level. The P-value for the F- statistic was applied in determining the robustness of the model. If the P-value is less than 0.05 , then it would be concluded that the model is significant and has good predictors of the dependent variable and the results are not based on chance. If the P-value is greater than 0.05 then the model would not be significant and cannot be used to explain the variations of the dependent variable. Similarly, the t-test statistic was used to test the significance of each 
individual predictor or independent variable and hypothesis. The P-value of each t-test was used to make conclusions on whether to fail to accept or fail to reject the null hypotheses. The benchmark for this study for failure to reject or failure to accept the null hypothesis is at a level of significance of 5 percent.

\subsubsection{Moderated Multiple Regression Model}

The Moderated model is shown as:

$Y=\beta_{0}+\beta_{1} \mathbf{x}_{i}+\beta_{2} M+\beta_{3} X_{i} M+e_{5}$

Where:

The dependent variable $Y$ is the financial performance of DT-SACCOs in Kenya variable which in this case it was aggregated from the return on Investment. The independent variable $X$ is the aggregate business management training. These are aggregated from Accounting Skills, Entrepreneurship Skills, Financial Management Skills, Marketing Skills and Strategic Leadership Skills. Variable $Z$ is the hypothesized moderator (SACCO Regulation) of relationship between variables $X$ and $Y$.

\section{Data Analysis, Presentation And Discussion}

\subsection{Inferential Statistics}

Inferential analysis was conducted to generate correlation results, model of fitness, and analysis of the variance and regression coefficients. Thus, inferential statistics were used to make inferences from the data to more general conditions.

\subsection{Reliability Analysis}

The study sought to ensure that the research scales were reliable. The reliability of an instrument refers to its ability to produce consistent and stable measurements. Chaffey (1994) explains that reliability can be seen from two sides: reliability (the extent of accuracy) and unreliability (the extent of inaccuracy). Cronchbach's alpha coefficient, which is a measure of internal consistency, was calculated by application of SPSS. Cronchbach's alpha ranges between $0-1$. A higher the coefficient, the more reliable is the test. In this study, the findings indicated that accounting skills had a coefficient of 0.959; Entrepreneurial skills had a coefficient of 0.954; financial management skills 0.940; marketing skills 0.955 and strategic leadership skills 0.958 . Table1 illustrates the reliability analysis. It involved questionnaires from 40 respondents.

Table1. Test of Reliability

\begin{tabular}{|l|l|l|}
\hline \multicolumn{1}{|c|}{ Research Variable } & \multicolumn{1}{c|}{ Reliability Value } & \multicolumn{1}{c|}{ Remarks } \\
\hline Accounting skills & 0.959 & Adequate \\
\hline Entrepreneurship skills & 0.954 & Adequate \\
\hline Financial management skills & 0.940 & Adequate \\
\hline Marketing skills & 0.955 & Adequate \\
\hline Strategic leadership skills & 0.958 & Adequate \\
\hline Overall (all variables) & 0.953 & Adequate \\
\hline
\end{tabular}

Source: Research data, 2018

As shown in table 4.9, all the research constructs had alpha coefficients of above 0.7. The overall Cronchbach's coefficient was 0.953 . Overall, the instrument met the recommended threshold of 0.7 (Nunnally\& Bernstein, 1994) and thus was it considered reliable.

\subsection{Test for Assumptions of Regression Analysis}

Since regression analysis was used as the main analysis technique, the assumptions of linearity and homoscedasticity, normality and multicollinearity were used. This section presents the results of the test.

\subsubsection{Linearity and Homoscedasticity}

To test for linearity and homoscedasticity, a scatter plot of standardized residuals (ZRESID) against standardized predicted (ZPRED) values was used. Figure1 shows the graph for the data. 


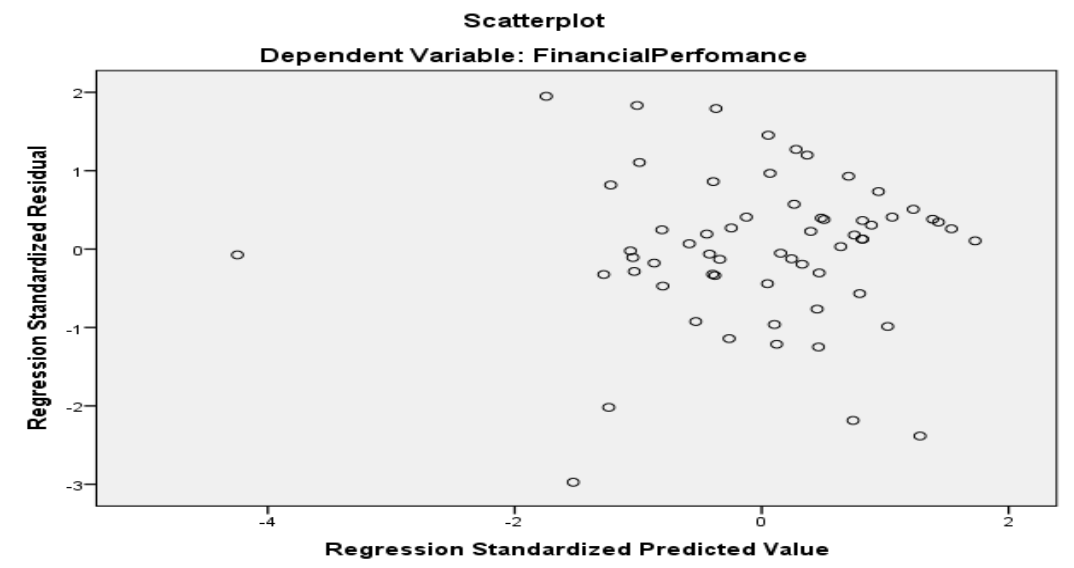

Figure1. Scatter plot of ZRESID against ZPRED

From figure 4.1 data points are randomly and evenly dispersed around zero. The graph does not funnel out and there is no sort of curve in the graph. This pattern indicates that the assumptions of linearity and homoscedasticity are therefore met.

\subsubsection{Test for Normality}

To test for normality, the normal probability plot was used; and the plotted data values were compared with the diagonal. Figure 4.2 shows the results of the test for normality.

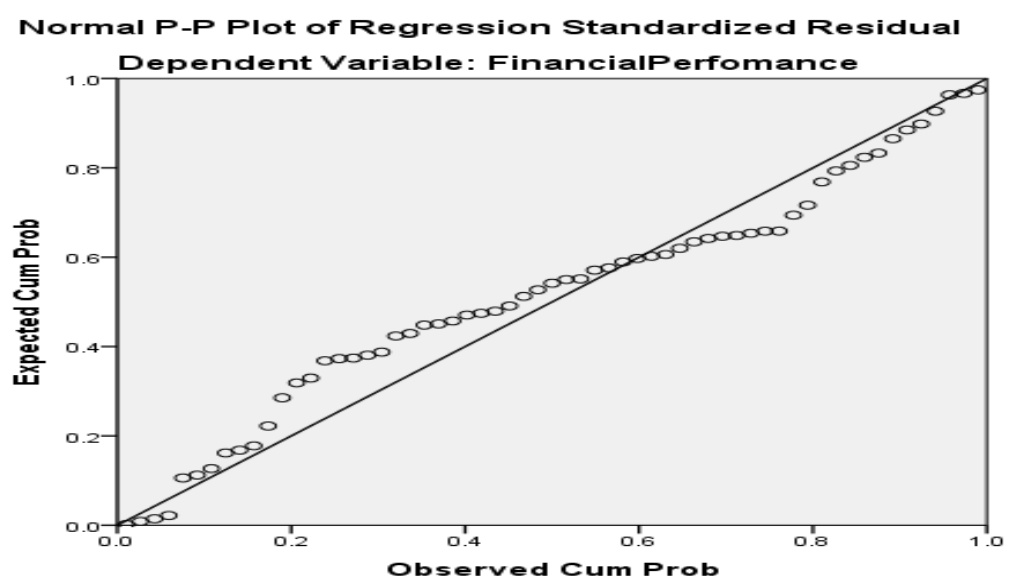

Figure2. Normal Probability Plot

As shown in Figure 4.2, the line representing the actual data distribution is a straight line following the diagonal indicating normal distribution of the data. Hence the survey data met the normality assumption.

\subsubsection{Multicollinearity Test}

A situation in which there is a high degree of association between the independent variables is said to be a problem of multicollinearity. Multicollinearity can also be solved by deleting one of the highly correlated variables. Heteroscedasticity means that previous error terms are influencing the other error terms and this violates the statistical assumption that the error terms have a constant variance. To test for multicollinearity of the predictor variables in the study, the diagnosis of tolerance and variance inflation factor (VIF) were used. The researcher therefore proceeded with regression analysis. The results of the analysis were presented in the preceding table 4.12.

\subsection{Correlation Analysis}

Correlation coefficients measure the strength of association between two variables. A positive correlation indicates the extent to which those variables increase or decrease in parallel; a negative correlation indicates the extent to which one variable increases as the other decreases. To be precise, it measures the extent of association between the ordering of two random variables although; a significant correlation does not necessarily indicate causality but rather a common linkage in a 
sequence of events. Thus, the study analyzed the relationships that are inherent among the independent and dependent variables as well as among the independent variables/ factors. The results regarding this were summarized and presented in table 4.9

Table2. Correlation Analysis

\begin{tabular}{|l|l|l|}
\hline \multicolumn{2}{|l|}{} & Financial Performance \\
\hline \multirow{3}{*}{ Accounting Skills } & Pearson Correlation & $.480^{* *}$ \\
\cline { 2 - 3 } & Sig. (2-tailed) & .000 \\
\cline { 2 - 3 } & $\mathrm{N}$ & 61 \\
\hline \multirow{5}{*}{ Entrepreneurships kills } & Pearson Correlation & $.439^{* *}$ \\
\cline { 2 - 3 } & Sig. (2-tailed) & .000 \\
\cline { 2 - 3 } & $\mathrm{N}$ & 61 \\
\hline \multirow{5}{*}{ Marketing Skills } & Pearson Correlation & .406 \\
\cline { 2 - 3 } & Sig. (2-tailed) & .001 \\
\cline { 2 - 3 } & $\mathrm{N}$ & 61 \\
\hline Strategic Leadership Skills & Pearson Correlation & $.380^{* * *}$ \\
\cline { 2 - 3 } & Sig. (2-tailed) & .003 \\
\cline { 2 - 3 } & $\mathrm{N}$ & 61 \\
\hline & Pearson Correlation & $.562^{* *}$ \\
\cline { 2 - 3 } & Sig. (2-tailed) & .000 \\
\cline { 2 - 3 } & $\mathrm{N}$ & 61 \\
\hline
\end{tabular}

Source: Research data, 2018

The correlation results in table 2 show a significant positive relationship between acquired accounting skills and financial performance (Pearson's $\mathrm{r}=0.48, \mathrm{P}<0.05$ ). The results also show that the relationship between acquired entrepreneurship skills and financial performance is positive and significant $(\mathrm{r}=0.439, \mathrm{p}<0.05)$. The correlation results also reveal that there is a significant positive relationship between acquired financial management skills and financial performance $(r=0.406, p<$ 0.05). Further, the results show a significant positive relationship between acquired marketing skills and financial performance $(\mathrm{r}=0.380, \mathrm{p}<0.05)$; and a significant positive relationship between acquired strategic leadership skills and financial performance $(\mathrm{r}=0.562, \mathrm{p}<0.05)$.these results are consistent with past findings which found a positive relationship between training and financial performance (Aragon and Valle, 2013). The results also support the findings of Percival, Cozzarin and Formaneck (2013) showed that training has a positive effect on productivity in 12 out of 14 manufacturing companies examined in Canada.

Table3. Coefficient of Determination of the Effect of Business Management Training on Financial Performance of DT-Sacco's In Kenya.

\begin{tabular}{|c|c|c|c|c|c|c|c|c|}
\hline \multirow{2}{*}{\multicolumn{2}{|c|}{ Model }} & \multicolumn{2}{|c|}{$\begin{array}{l}\text { Unstandardized } \\
\text { Coefficients }\end{array}$} & \multirow{2}{*}{$\begin{array}{c}\text { Standardized } \\
\text { Coefficients } \\
\text { Beta } \\
\end{array}$} & \multirow[t]{2}{*}{$\mathbf{t}$} & \multirow[t]{2}{*}{ Sig. } & \multicolumn{2}{|c|}{$\begin{array}{l}\text { Collinearity } \\
\text { Statistics }\end{array}$} \\
\hline & & B & Std. Error & & & & Tolerance & VIF \\
\hline \multirow[t]{6}{*}{1} & (Constant) & .482 & .714 & & .675 & .502 & & \\
\hline & Account & .150 & .137 & .148 & 1.088 & .041 & .572 & 1.748 \\
\hline & Entrepreneurship Skills & .118 & .076 & .186 & 1.547 & .038 & .739 & 1.353 \\
\hline & Financial Management Skills & .108 & .187 & .077 & .578 & .045 & .606 & 1.650 \\
\hline & Marketing Skills & .130 & .158 & .103 & .824 & .014 & .687 & 1.455 \\
\hline & Leadership Skills & .387 & .147 & .340 & 2.626 & .011 & .636 & 1.572 \\
\hline
\end{tabular}

a. Dependent Variable: Financial Performance

b. Predictors: (Constant), Leadership Skills, Marketing Skills, Entrepreneurship Skills, Financial Management Skills, Accounting Skills

Information in Table 3 indicates the prediction equation is Financial Performance of DT-SACCOs in Kenya $=.482+.150$ (Accounting Skills) +.118 (Entrepreneurship Skills) +.108 (Financial Management Skills) +.130 (Marketing Skills) +.387 (Leadership Skills). The standard error was (0.714), being an estimate of the standard deviation of the coefficient, is a random variable with a mean of zero and which captured the variables that could not be quantified. If a coefficient is large compared to its standard error, then it is probably different from 0 .

After regression, the coefficient model took this form:

Financial performance $=0.482+0.150 \mathrm{X} 1+0.118 \mathrm{X} 2+0.108 \mathrm{X} 3+0.130 \mathrm{X} 4+0.387 \mathrm{X} 5$ 
Where; $\mathrm{X} 1$ = accounting skills, $\mathrm{X} 2$ = entrepreneurship skills, $\mathrm{X} 3$ = financial management skills, $\mathrm{X} 4$ = marketing skills and X5 = strategic leadership skills.

Table4. Moderation effect of SASRA Regulations on relationship between Business Management Training and Financial Performance

Model Summary

\begin{tabular}{|c|c|c|c|c|c|c|c|c|c|}
\hline \multirow[t]{2}{*}{ Model } & \multirow[t]{2}{*}{$\mathbf{R}$} & \multirow{2}{*}{$\begin{array}{c}\text { R } \\
\text { Square }\end{array}$} & \multirow{2}{*}{$\begin{array}{l}\text { Adjusted } \\
\text { R Square }\end{array}$} & \multirow{2}{*}{$\begin{array}{l}\text { Std. Error } \\
\text { of the } \\
\text { Estimate }\end{array}$} & \multicolumn{5}{|c|}{ Change Statistics } \\
\hline & & & & & $\begin{array}{l}\text { R Square } \\
\text { Change }\end{array}$ & $\begin{array}{c}\mathbf{F} \\
\text { Change }\end{array}$ & df1 & df2 & $\begin{array}{c}\text { Sig. F } \\
\text { Change }\end{array}$ \\
\hline 1 & $.622^{\mathrm{a}}$ & .387 & .376 & .51999 & .387 & 37.210 & 1 & 59 & .000 \\
\hline 2 & $1.000^{\mathrm{b}}$ & 1.000 & 1.000 & .00000 & .613 & . & 1 & 58 & . \\
\hline
\end{tabular}

ANOVA Table

\begin{tabular}{|c|l|l|l|l|l|c|}
\hline \multicolumn{2}{|c|}{ Model } & Sum of Squares & \multicolumn{1}{c|}{ Df } & Mean Square & F & Sig. \\
\hline \multirow{2}{*}{1} & Regression & 10.061 & 1 & 10.061 & 37.210 & $.000^{\mathrm{b}}$ \\
\cline { 2 - 7 } & Residual & 15.953 & 59 & .270 & & \\
\cline { 2 - 7 } & Total & 26.014 & 60 & & & \\
\hline \multirow{2}{*}{2} & Regression & 26.014 & 2 & 13.007 & 24.346 & $.000^{\mathrm{c}}$ \\
\cline { 2 - 7 } & Residual & 41.010 & 58 & .294 & & \\
\cline { 2 - 7 } & Total & 67.024 & 60 & & & \\
\hline
\end{tabular}

a. Dependent Variable: Financial Performance

b. Predictors: (Constant), Business Management Training

c. Predictors: (Constant), Business Management Training, SASRA Regulations

R Square Change, 0.613 shows that addition of SASRA Regulations to the model leads to $61.3 \%$ increase in variation of financial performance. Sig. F Change value of $0.000(<0.05)$ indicates that the increase is statistically significant. ANOVA table shows that the model is statistically significant at $\mathrm{F}=24.346$ and $\mathrm{p}=0.000(<0.05)$. The last hypothesis was therefore rejected and conclusion made that SASRA Regulations have statistically significant moderating effect on the relationship between Business Management Training and Financial Performance

\subsection{Hypotheses Testing}

This section presents analysis and results of the tests of hypotheses using inferential statistics. The section presents results of statistical analyses and interpretations of the results in relation to the research hypotheses.

Table5. Summary of results of tests of hypothesis and related objectives

\begin{tabular}{|c|c|c|c|}
\hline Objectives & Hypothesis & Result & $\begin{array}{l}\text { Remarks on } \\
\text { hypothesis }\end{array}$ \\
\hline $\begin{array}{l}\text { Objective } 1 \\
\text { To assess the effect of acquired } \\
\text { accounting skills on financial } \\
\text { performance of DT-SACCOs }\end{array}$ & $\begin{array}{l}\mathrm{H}_{01} \text { : Acquired Accounting skills } \\
\text { have no statistically significant } \\
\text { effect on financial performance } \\
\text { of DT-SACCOs }\end{array}$ & $\begin{array}{l}\mathrm{t}=1.088 ; \quad \mathrm{p}=0.041 \\
(<0.05) \\
\text { Which is less than } 0.05\end{array}$ & Rejected \\
\hline $\begin{array}{l}\text { Objective } 2 \\
\text { To establish the effect of acquire d } \\
\text { entrepreneurship skills on financial } \\
\text { performance of DT-SACCOs }\end{array}$ & $\begin{array}{l}\mathrm{H}_{02}: \text { Acquired } \\
\text { skills have no statistically } \\
\text { significant effect on financial } \\
\text { performance of DT-SACCOs }\end{array}$ & $\begin{array}{l}\mathrm{t}=1.547 ; \quad \mathrm{p}=0.028 \\
(<0.05) \\
\text { Which is less than } 0.05\end{array}$ & Rejected \\
\hline $\begin{array}{l}\text { Objective } 3 \\
\text { To determine the effect of } \\
\text { acquired financial management } \\
\text { skills on financial performance of } \\
\text { DT-SACCOs }\end{array}$ & $\begin{array}{l}\mathrm{H}_{03} \text { : There is no statistically } \\
\text { significant effect of acquired } \\
\text { financial management skills on } \\
\text { financial performance of DT- } \\
\text { SACCOs }\end{array}$ & $\begin{array}{l}\mathrm{t}=0.578 ; \quad \mathrm{p}=0.045 \\
(<0.05) \\
\text { Which is less than } 0.05\end{array}$ & Rejected \\
\hline $\begin{array}{l}\text { Objective } 4 \\
\text { To establish the effect of acquired } \\
\text { marketing skills on financial } \\
\text { performance of DT-SACCOs }\end{array}$ & $\begin{array}{l}\mathrm{H}_{04}: \text { There is no statistically } \\
\text { significant effect of acquired } \\
\text { marketing skills on financial } \\
\text { performance of DT-SACCOs }\end{array}$ & $\begin{array}{l}\mathrm{t}=0.824 ; \quad \mathrm{p}=0.014 \\
(<0.05) \\
\text { Which is less than } 0.05\end{array}$ & Rejected \\
\hline $\begin{array}{l}\text { Objective } 5 \\
\text { To determine the effect of acquired } \\
\text { Strategic Leadership skills on finan } \\
\text { cial performance of DT-SACCOs }\end{array}$ & $\begin{array}{l}\mathrm{H}_{05}: \text { There is no statistically } \\
\text { significant effect of acquired Strate } \\
\text { gic Leadership skills on financial } \\
\text { performance of DT-SACCOs }\end{array}$ & $\begin{array}{l}\mathrm{t}=2.626 ; \quad \mathrm{p}=0.011 \\
(<0.05) \\
\text { Which is less than } 0.05\end{array}$ & Rejected \\
\hline
\end{tabular}




\begin{tabular}{|l|l|l|l|}
\hline Objective 6 & Ho6: There is no statistically & $\mathrm{F}=24.346$ and $\mathrm{p}=0.000$ & Rejected \\
To find out the moderating effect of & significant moderating effect of & $(<0.05)$. & \\
SASRA regulation on the & SASRA regulation on the & Which is less than 0.05 & \\
relationship between business & relationship between business & & \\
management training and financi al & management training and financial & & \\
performance of DT-SACCOs & performance of DT-SACCOs. & & \\
\hline
\end{tabular}

Source: Researcher, 2018

\section{SUMmaRY OF FINDINGS, CONCLUSIONS AND RECOMMENDATIONS}

\subsection{Summary of Findings}

This study examined the effect of business management training on financial performance of DTSACCOs. The data for the study was gathered both from primary and secondary sources, analyzed and interpreted and the results were summarized as per the research objectives. The research problem was to establish the effect of business management training on financial performance of deposit taking SACCOs in Kenya. The data for the study was collected from 74 DT-SACCOs. The findings revealed that the DT-SACCOs to a great extent receive business management training by KUSCCO and other NITTA accredited consultants.

\subsection{Recommendations of the Study}

This study was based on theory of internal control, psychological theory, financial stewardship theory, resource-based theory and porter's theory of competitive advantage to assess the effect of acquired accounting skills on financial performance; to establish the effect of acquired entrepreneurship skills on financial performance; to determine the effect of acquired financial management skills on financial performance; to establish the effect of acquired marketing skills on financial performance; to determine the effect of acquired Strategic Leadership skills on financial performance of DT-SACCOs; to find out the moderating effect of SASRA regulation on the relationship between business management training and financial performance of DT-SACCOs; to determine the effect of the independent variables: acquired accounting skills, entrepreneurship skills, financial management skills, marketing skills and strategic leadership on financial performance of DT-SACCOs. The findings of the study conducted in DT-SACCOs in Kenya have various implications for management policy and practice as explained below.

\subsection{Areas for Further Research}

This study contributes to the understanding of the effect of business management training on financial performance. However, further research is necessary to address some of the limitations of this study and extend this stream of research. The study should be replicated in others sectors and other countries. Such replication could further determine whether the result of this study can be generalized to other sectors or countries with different contextual conditions. This will enhance understanding of the relationship between business management training and financial performance in different contexts.

The respondents of this study were executive officers and three respondents were used in each DTSACCO to collect data. To minimize the effect of triple respondents' bias, future research can use many more respondents including executive officers, middle and lower level managers. Future studies may consider inclusion of other organizational variables which may influence the relationship between business management training and financial performance either as moderating or mediating variables. These variables may include organizational resources, technology, age and size.

\section{REFERENCES}

[1] Abdel-Kader, M., \& Luther, R. (2004).An Empirical Investigation of the Evolution of Management Accounting Practices. Working paper No. 04 / 06. 1-25

[2] Abdulla, H.,\& Valentine, B. (2009). Fundamental and Ethics Theories of Corporate Governance. Journal of Middle Eastern Finance and Economics, 4(2), 88-96.

[3] Adeniji, A, A., Osibanjo, A.O,, \& Abiodun, A.J.(2013). Organizational Change and Human Resource Management interventions; An Investigation of the Nigeria Banking Industry: Serbian Journal of Management, 8(2): 845-867.

[4] Ahmad, Z.K., \&Bakar, R. A. (2003).“The Association Between Training And Organizational Commitment Among White- Collar Workers In Malaysia”, International Journal of Training and Development, 7(3), 166-85. 
[5] Ahl, H. (2006). Why research on women entrepreneurs needs new directions. Entrepreneurship Theory and Practice, 30(5), 595-621.

[6] Bamford, C. E, Dean, T. J., \&Doglas, T. J. (2004). "The Temporal Nature of Growth Determinants in New Bank Foundings: Implications of New Venture Research Design.” Journal of Business Venturing, 19, 899919.

[7] Banning, K. (2013). Shareholder Wealth Effects of C.E.Os Succession. American Journal of Industrial and Business Management, 3, 583-588.

[8] Barclays Bank. (1994). Bridging the Skills Gap, Barclays Bank plc, London.

[9] Barnabas, C. (2011). Internal Control. Cede Publishing.

[10] Rowden, R.W. \&Conine, C.T.(2005). "The impact of workplace learning and job satisfaction in small US commercial banks", Journal of workplace Learning, Vol. 17 No. 4, pp. 215-30.

[11] Roos, G., Roos. J. \&Edvinsson, L. (2012). Intellectual Capital. Realizing Your Company's True Value by Finding Its Hidden Brainpower.

[12] Ross, S. A. (1998). Fundamentals of Corporate Finance. $4^{\text {th }}$ Edition. New York, U.S..A: McGraw Hill.

[13] Ross, S. A. (1973). "The Economic Theory of Agency. The Principals problem. "The American Economic Review, Vol. 63, No.2, pp. 133-139.

[14] Rotter, J. (1966). “Generalized Expectancies for Internal Versus External Control Reinforcements", Psychological Monographs, 80, Whole9 No.60.

Citation: Ezra K. Ronoh. "Effect of Business Management Training on Financial Performance of Deposit Taking Saccos in Kenya". International Journal of Managerial Studies and Research (IJMSR), vol 6, no. 11, 2018, pp. 104-115. doi: http://dx.doi.org/10.20431/2349-0349.0611011.

Copyright: (C) 2018 Authors. This is an open-access article distributed under the terms of the Creative Commons Attribution License, which permits unrestricted use, distribution, and reproduction in any medium, provided the original author and source are credited. 